\title{
PCM1/JAK2 Fusion Gene
}

National Cancer Institute

\section{Source}

National Cancer Institute. PCM1/JAK2 Fusion Gene. NCI Thesaurus. Code C129855.

A fusion gene that results from a chromosomal translocation $\mathrm{t}(8 ; 9)(\mathrm{p} 22 ; \mathrm{p} 24.1)$ which fuses most of the PCM1 gene to the upstream side of the exons of the JAK2 gene encoding the tyrosine kinase domain. This fusion is associated with myeloproliferative disorders and some rare myeloid and lymphoid neoplastic diseases. 